TECHNICAL SCIENCES AND TECHNOLOGIES

UDC 621.396

DOI: $10.25140 / 2411-5363-2019-3(17)-209-218$

Viktor Kovalenko, Serhii Levchenko, Mykola Tryputen, Vitaliy Kuznetsov, Maksym Tryputen, Oleksiy Gorodny, Alisa Kuznetsova, Yevheniia Kuznetsova

\title{
CHARACTERISTIC LAYOUTS OF DISTRIBUTION NETWORKS WITH THE ANALYSIS OF VOLTAGE DEVIATIONS AND EXPEDIENCY OF ITS CONTROL
}

Urgency of the research. It is well-known that electric energy characteristics are the levels of electromagnetic compatibility of electric grid providing adequate performance of any electrical means connected to the grid if the electric energy characteristics do not exceed permitted values. In the context of general idea of electromagnetic compatibility of consumers within power supply grids, power quality is the topical problem of modern electric-power supply industry.

Target setting. The issue of assessing the possibility of ensuring the quality of electricity in terms of voltage deviation by consumers is very important. The problem of voltage fluctuations is relevant, so that voltage deviation have a negative impact on functioning electrical equipment

Actual scientific researches and issues analysis. Papers [2-11] are devouted the effective management methods of electrical energy consumption. The articles [6-8] shows that under present conditions only system approach ensures accurate identification and prediction of electric power losses in distribution networks that are characterized by considerable ambiguity.

Uninvestigated parts of general matters defining. Generalized diagram of the voltage modes characterizes the state for the entire distribution network connected to the main substation; it consists of the branched $10 \mathrm{kV}$ network, all the distribution transformers, and all the $0.4 \mathrm{kV}$ networks connected to those transformers. Along with the generalized diagram, values of the available voltage losses have been obtained; those values occur within $10 \mathrm{kV}$ and $0.4 \mathrm{kV}$ networks in terms of the favourable conditions of voltage control and the initial values of the admissible voltage deviations of electrical receivers. Moreover, that is the basis to determine operating position of control tappings of distribution transformers.

The research objective. Since one of the important characteristics of electrical energy is the deviation of the voltage in the network, it is advisable to carry out its analysis in the urban distribution networks in terms of Levanevska substation, town of Zaporizhzhia. To simplify practical representation of possible voltage modes on the main substation buses and within the whole distribution networks, it is expedient to use graphic representation - so-called generalized diagram of voltage modes. That diagram helps make the analysis of voltage modes more demonstrative than analytical calculation; besides, the diagram gives great possibilities for further study.

The statement of basic materials. While analyzing voltage mode in the distribution networks and determining the required law of voltage control in the main substation (MS), one should take into consideration great amount of factors effecting and complicating that study. Those factors include the following: changes in the operating mode of the network, differences in the points of connections of electrical receivers (ER) to the distribution network, differences in possible operating positions of the control tappings in the distribution transformers (DT), differences in the points of DT connections to $10 \mathrm{kV}$ network, available dead zones of automatic voltage controller etc. Owing to that fact, it is required to perform generalized analysis of the voltage mode and conditions of its control within $10 \mathrm{kV}$ and $0.4 \mathrm{kV}$ distribution networks and on main substation buses. To do that, one should apply probabilistic calculation methods. At the same time, it is expedient to use graphic depiction (so-called generalized diagram (GD) of the voltage modes) to simplify representation of possible voltage modes on MS buses and within the whole distribution network. That diagram will help make the analysis of the voltage modes more clearly arranged than analytic calculations; moreover, it gives great opportunities for further study.

Conclusions. Voltage deviation in the distribution networks has been performed and expediency of the voltage deviation control for electrically closest and farthest consumers have been analyzed in terms of Levanevska substation, town of Zaporizhzhia. Expediency of practical application of generalized diagrams for that purpose has been demonstrated. It has been defined that in the modes of maximum and minimum loads, voltage exceeds the admissible deviation norms of $\pm 5 \%$. Conclusion has been made on the expediency of more careful voltage control. Generalized diagram for 0-1 and 9-10 hours with the maximum voltage deviations has been constructed. Graph of dependences has been developed; formula of voltage deviations in the main substation, due to the voltage passing along that line, has been defined. According to the voltage data before and after the implementation of control, graphs of voltage deviations on the distribution transformer and in terms of the farthest consumer have been constructed.

Keywords: distribution networks; main substation; voltage deviation; transformer load; transformer voltage control (TVC); generalized diagram.

Table: 4. Fig.: 7. References: 11.

Urgency of the research. It is common knowledge that electric energy characteristics are the levels of electromagnetic compatibility of electric grid providing adequate performance of any electrical means connected to the grid if the electric energy characteristics do not exceed permitted values. In the context of general idea of electromagnetic compatibility of consumers within power supply grids, power quality is the topical problem of modern electric-power supply industry.

Target setting. The issue of assessing the possibility of ensuring the quality of electricity in terms of voltage deviation by consumers is very important. The problem of voltage fluctuations is relevant, so that voltage deviation have a negative impact on functioning electrical equipment.

(c) Коваленко В. Л., Левченко С. А., Трипутень М. М., Кузнецов В. В., Трипутень М. М., Городній О. М., Кузнецова А. В., Кузнецова С. В., 2019 
TECHNICAL SCIENCES AND TECHNOLOGIES

Actual scientific researches and issues analysis. Papers [2-11] are devouted the effective management methods of electrical energy consumption. The articles [6-8] shows that under present conditions only system approach ensures accurate identification and prediction of electric power losses in distribution networks that are characterized by considerable ambiguity.

Uninvestigated parts of general matters defining. Generalized diagram of the voltage modes characterizes the state for the entire distribution network connected to the main substation; it consists of the branched $10 \mathrm{kV}$ network, all the distribution transformers, and all the $0.4 \mathrm{kV}$ networks connected to those transformers. Along with the generalized diagram, values of the available voltage losses have been obtained; those values occur within $10 \mathrm{kV}$ and $0.4 \mathrm{kV}$ networks in terms of the favourable conditions of voltage control and the initial values of the admissible voltage deviations of electrical receivers. Moreover, that is the basis to determine operating position of control tappings of distribution transformers.

The research objective. Since one of the important characteristics of electrical energy is the deviation of the voltage in the network, it is advisable to carry out its analysis in the urban distribution networks in terms of Levanevska substation, town of Zaporizhzhia. To simplify practical representation of possible voltage modes on the main substation buses and within the whole distribution networks, it is expedient to use graphic representation - so-called generalized diagram of voltage modes. That diagram helps make the analysis of voltage modes more demonstrative than analytical calculation; besides, the diagram gives great possibilities for further study.

The statement of basic materials. While analyzing voltage mode in the distribution networks and determining the required law of voltage control in the main substation (MS), one should take into consideration great amount of factors effecting and complicating that study. Those factors include the following: changes in the operating mode of the network, differences in the points of connections of electrical receivers (ER) to the distribution network, differences in possible operating positions of the control tappings in the distribution transformers (DT), differences in the points of DT connections to $10 \mathrm{kV}$ network, available dead zones of automatic voltage controller etc. Owing to that fact, it is required to perform generalized analysis of the voltage mode and conditions of its control within $10 \mathrm{kV}$ and $0.4 \mathrm{kV}$ distribution networks and on main substation buses.

To do that, one should apply probabilistic calculation methods. At the same time, it is expedient to use graphic depiction (so-called generalized diagram (GD) of the voltage modes) to simplify representation of possible voltage modes on MS buses and within the whole distribution network. That diagram will help make the analysis of the voltage modes more clearly arranged than analytic calculations; moreover, it gives great opportunities for further study.

Generalized diagram of the voltage modes characterizes the situation for the entire distribution network connected to MS; the diagram consists of the branched $10 \mathrm{kV}$ network, all the DTs, and all the $0.4 \mathrm{kV}$ networks connected to those transformers. Fig. 1 demonstrates principal diagram of the mentioned distribution network. In this context, it means that DT may be switched on at any point of $0.4 \mathrm{kV}$ network, and ER may be connected at any point of $0.4 \mathrm{kV}$ distribution network.

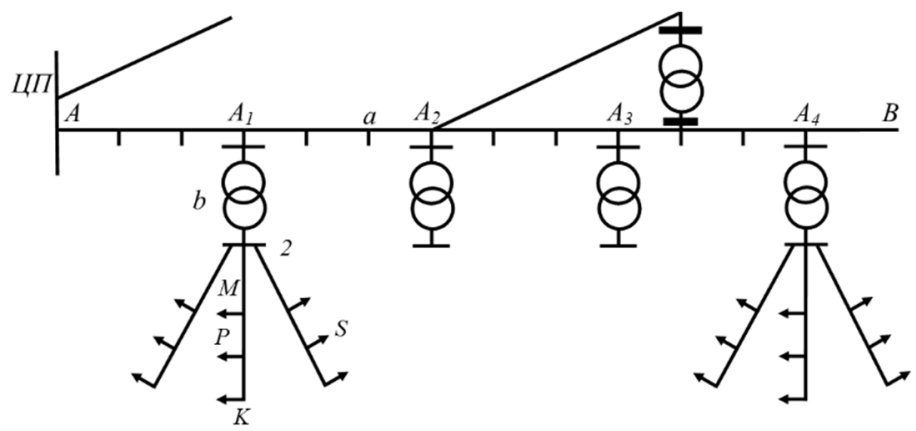

Fig. 1. Principle diagram of $10 \mathrm{kV}$ and $0.4 \mathrm{kV}$ distribution network:

$a-10 \mathrm{kV}$ network; $b$-distribution transformers (DT); c-0.4 kV network; $d$-electrical receivers (ER) 
TECHNICAL SCIENCES AND TECHNOLOGIES

GD is the basis to determine conditions of voltage control on MS buses in terms of which deviations from nominal voltage on ER clamps connected to the mentioned distribution networks are within the admissible limits. Along with GD, values of the available voltage losses may be obtained; those losses may be observed within $10 \mathrm{kV}$ and $0.4 \mathrm{kV}$ networks in terms of the adopted conditions of voltage control in MS and the initial values of the admissible voltage deviations in ER. Moreover, that is the basis to define operating position of DT control tappings.

While constructing generalized diagram of voltage modes, assumption is made on the fact that all the values of voltage losses from MS to each network point and from each network point to any ER are changing in a mutually proportional way. That assumption simplifies to certain extent graphic representation of the aforementioned values and construction of the generalized diagram on the whole. However, it meets the condition of homogeneity of all the connected power consumers in terms of the convergence (with practically adopted degree of accuracy) of their load diagrams.

In terms of urban networks, that condition is true to some extent only for public utility loads. Other consumers (educational institutions, trade organizations, industrial and tractive facilities) may differ considerably in their load diagrams.

Following condition is taken as the validation criterion to solve the problem of voltage control in MS: voltage deviation from the nominal value for all ERs connected to the network should not be beyond the limits of the admissible values [1]. In this context, all the network sites and all the loads are considered to be three-phase and symmetric. As it has been already mentioned, that condition is somehow idealized. Available three-phase loads, tappings, and differences in the phase properties within certain sections of a three-phase network result in asymmetric voltages and increased actual voltage deviations in ER comparing to the calculated values obtained for the mentioned idealized conditions. In practice, voltage loss on zero wire may be up to $25 \%$ (sometimes, up to $50 \%$ ) of the voltage loss in phase wires. Thus, calculation values of the admissible voltage losses should be reduced by not less than $0.5-1 \%$, i.e. they should be taken within the range of $\pm 4.5-4 \%$ instead of $\pm 5 \%$ of the nominal voltage. Nevertheless, that will result practically in the unjustified cost rising of $10 \mathrm{kV}$ network since the actual situation cannot be determined by the simplified calculation.

In terms of simplified analysis of voltage modes, two boundary operating modes are considered: maximum and minimum loads. In the context of the favourable initial conditions, all other possible operating modes of the network are intermediate. Voltage deviations from the nominal value in the maximum-load mode at the network point are marked as $\mathrm{V}^{\prime}$; in terms of minimum-load mode, they are identified as V" (Fig. 2).

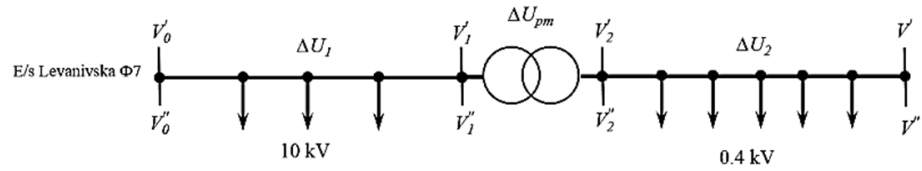

Fig. 2. Diagram of substitution of the distribution network

Tables 1 and 2 represent parameters of electrically closest and farthest points of $0.4 \mathrm{kV}$ and $10 \mathrm{kV}$ feeder $\Phi-7$ of Levanevska electric substation, town of Zaporizhzhia.

While constructing diagrams, relative (in percentage form) values $\mathrm{V}^{\prime \prime}$ are laid along the abscissa axis, and values $\mathrm{V}^{\prime}$ are laid along the ordinates axis. According to the condition taken before, ER voltage should not go beyond the admissible limits of $\pm 5 \%$ of the nominal one; thus, it is possible to imagine corresponding range of admissible conditions of ER operation in the form of a square with the side of $10 \%$ and the center at the origin of coordinates. In terms of the adopted coordinate axes, voltage modes at each point of the network are characterized by certain point on the diagram, which coordinates define maximum and minimum voltage deviations. 
Parameters of $0.4 \mathrm{kV}$ network

\begin{tabular}{|c|c|c|c|c|}
\hline $\begin{array}{l}\text { Time, } \\
\text { hour }\end{array}$ & $\begin{array}{l}\text { Voltage of the } \\
\text { closest point, } V\end{array}$ & $\begin{array}{c}\text { Deviations from } \\
\text { the nominal value, } \%\end{array}$ & $\begin{array}{l}\text { Voltage of the } \\
\text { farthest point, } V\end{array}$ & $\begin{array}{c}\text { Deviations from } \\
\text { the nominal value, } \%\end{array}$ \\
\hline 1 & 2 & 3 & 4 & 5 \\
\hline 0 & 418 & 10.1 & 411 & 8.1 \\
\hline 1 & 418 & 10.1 & 411 & 8.1 \\
\hline 2 & 415 & 9.1 & 407 & 7.2 \\
\hline 3 & 415 & 9.1 & 407 & 7.2 \\
\hline 4 & 411 & 8.1 & 403 & 6.1 \\
\hline 5 & 405 & 6.7 & 397 & 4.4 \\
\hline 6 & 400 & 5.2 & 389 & 2.3 \\
\hline 7 & 389 & 2.4 & 374 & -1.5 \\
\hline 8 & 370 & -2.7 & 345 & -9.2 \\
\hline 9 & 377 & -0.9 & 354 & -6.8 \\
\hline 10 & 374 & -1.6 & 350 & -8.0 \\
\hline 11 & 386 & 1.5 & 369 & -3.0 \\
\hline 12 & 383 & 0.7 & 364 & -4.2 \\
\hline 13 & 377 & -0.9 & 354 & -6.8 \\
\hline 14 & 379 & -0.2 & 357 & -6.1 \\
\hline 15 & 392 & 3.3 & 371 & -2.3 \\
\hline 16 & 393 & 3.3 & 380 & -0.1 \\
\hline 17 & 395 & 4.0 & 383 & 0.8 \\
\hline 18 & 391 & 3.0 & 378 & -0.5 \\
\hline 19 & 402 & 5.9 & 392 & 3.1 \\
\hline 20 & 404 & 6.4 & 394 & 3.8 \\
\hline 21 & 408 & 7.4 & 398 & 4.7 \\
\hline 22 & 412 & 8.5 & 406 & 7.0 \\
\hline 23 & 418 & 10.0 & 410 & 7.8 \\
\hline
\end{tabular}

Table 2

Parameters of $10 \mathrm{kV}$ network

\begin{tabular}{|l|c|c|c|c|}
\hline $\begin{array}{c}\text { Time, } \\
\text { hour }\end{array}$ & $\begin{array}{c}\text { Voltage of the } \\
\text { closest point, } \mathbf{V}\end{array}$ & $\begin{array}{c}\text { Deviations from } \\
\text { the nominal value, } \%\end{array}$ & $\begin{array}{c}\text { Voltage of } \\
\text { the farthest point, V }\end{array}$ & $\begin{array}{c}\text { Deviations from } \\
\text { the nominal value, \% }\end{array}$ \\
\hline 0 & 10.7 & 7 & 10.2 & 2 \\
\hline 1 & 10.7 & 7 & 10.2 & 1 \\
\hline 2 & 10.6 & 6 & 10.1 & 1 \\
\hline 3 & 10.6 & 6 & 10.1 & 0 \\
\hline 4 & 10.6 & 6 & 9.9 & -1 \\
\hline 5 & 10.6 & 6 & 9.8 & -2 \\
\hline 6 & 10.6 & 6 & 9.6 & -4 \\
\hline 7 & 10.6 & 6 & 9.25 & -7.5 \\
\hline 8 & 10.3 & 3 & 9.4 & -6 \\
\hline 9 & 10.4 & 4 & 9.35 & -4.5 \\
\hline 10 & 10.3 & 3 & 9.55 & -5 \\
\hline 11 & 10.3 & 3 & 9.5 & -6 \\
\hline 12 & 10.4 & 4 & 9.4 & -5.5 \\
\hline 13 & 10.4 & 4 & 9.45 & -3.5 \\
\hline 14 & 10.4 & 4 & 9.65 & -3.5 \\
\hline 15 & 10.5 & 5 & 9.65 & -3 \\
\hline 16 & 10.5 & 5 & 9.7 & -3.8 \\
\hline 17 & 10.6 & 6 & 9.62 & -1.5 \\
\hline 18 & 10.6 & 6 & 9.85 & -1 \\
\hline 19 & 10.6 & 6 & 9.9 & 0 \\
\hline 20 & 10.6 & 6 & 10 & 2 \\
\hline 21 & 10.6 & 6 & 10.2 & \\
\hline 22 & 10.6 & 6 & & \\
\hline 23 & 10.6 & 6.1 & \\
\hline
\end{tabular}


TECHNICAL SCIENCES AND TECHNOLOGIES

Difference in ordinates of any two points along the straight line determines voltage loss between the corresponding line points in the mode of maximum loads; difference in abscissas defines the same but in terms of the mode of minimum loads.

Voltage deviations from the nominal values have been analyzed. It has been identified that in terms of the modes of maximum and minimum loads, voltage exceeds the admissible deviation norms of $\pm 5 \%$. Conclusion has been made on the expediency of better voltage control. Generalized diagram for 0-1 and 9-10 hours, having the greatest voltage deviations, has been constructed (Fig. 3, 4).

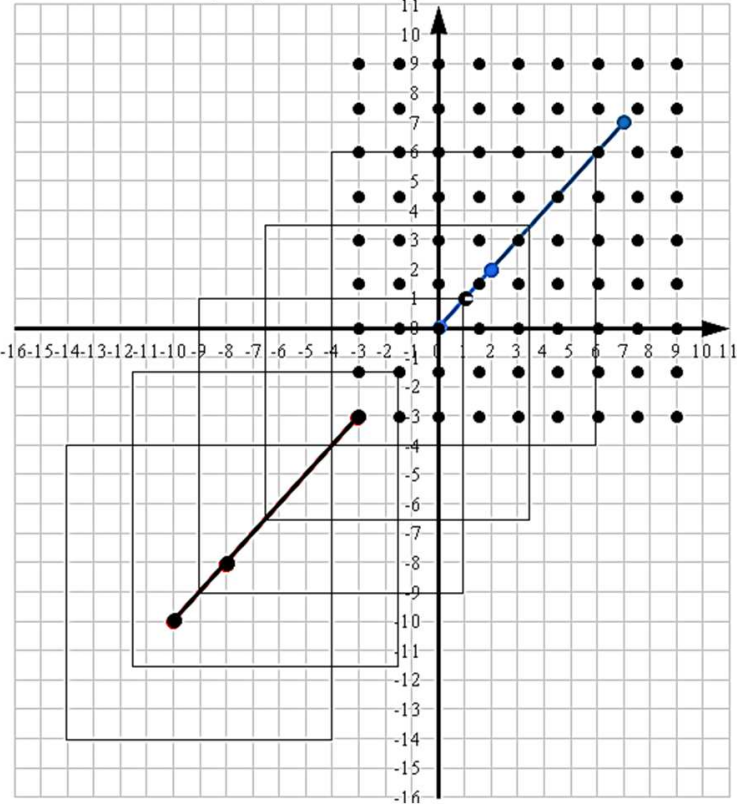

Fig. 3. Generalized diagrams for 0-1 hours

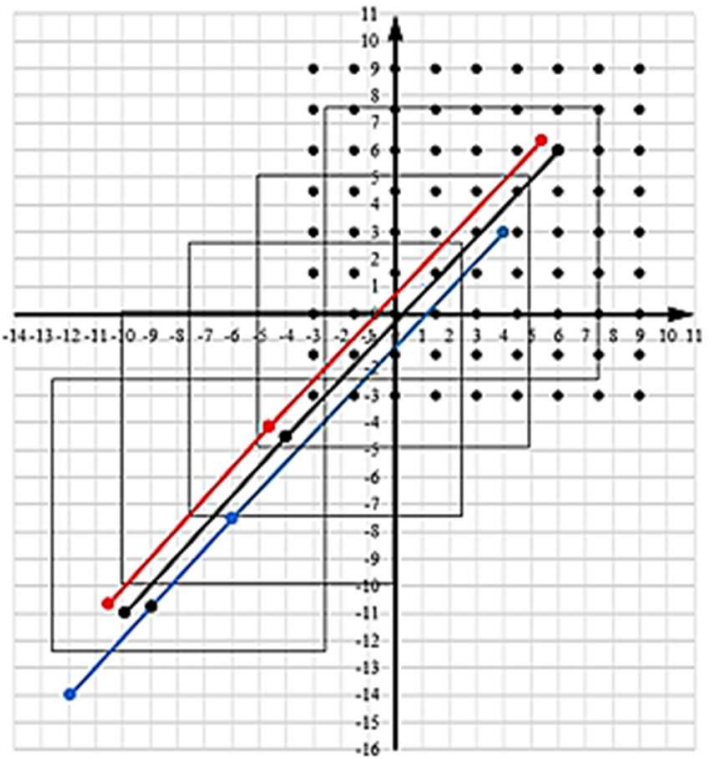

Fig. 4. Generalized diagrams for 9-10 hours

Possible variants of control highlighted in black dots are at the distance of $1.5 \%$ from each other according to the control step of the transformer voltage control in the main substation, i.e. at Levanevska substation. Blue colour shows operating modes of $10 \mathrm{kV}$ and $0.4 \mathrm{kV}$ networks for that system. Normal operating mode requires displacement of the system so that the center of $0.4 \mathrm{kV}$ network will coincide with the center of squares (it is represented in the red line) which shows tappings of distribution transformers. Since TVC allows controlling only in a steplike mode, then we use the closest control point for the main substation (black line).

Values of voltage deviation in the main substation with the closest TVC steps have been determined for each hour and represented in Table 3.

Table 3

Controle mode

\begin{tabular}{|l|c|c|c|}
\hline Time, hour & Voltage deviation in MS, $\%$ & TVC position & Power, $\mathbf{k V} \cdot \mathbf{A}$ \\
\hline \multicolumn{1}{|c|}{} & 2 & 3 & 4 \\
\hline 0 & -3.05 & -3 & 37 \\
\hline 1 & -3.05 & -3 & 37 \\
\hline 2 & -3.08 & -3 & 37 \\
\hline 3 & -3.08 & -3 & 37 \\
\hline 4 & -2.07 & -1.5 & 37 \\
\hline 5 & -0.68 & 0 & 44 \\
\hline 6 & 0.87 & 1.5 & 54 \\
\hline 7 & 2.70 & 3 & 69 \\
\hline 8 & 6.35 & 6 & 100 \\
\hline 9 & 5.39 & 6 & 94 \\
\hline 10 & 5.25 & 6 & 99 \\
\hline 11 & 2.40 & 3 & 77 \\
\hline
\end{tabular}


End Table 3

\begin{tabular}{|l|c|c|c|}
\hline \multicolumn{1}{|c|}{1} & 2 & 3 & 4 \\
\hline 12 & 3.61 & 3 & 83 \\
\hline 13 & 5.39 & 6 & 94 \\
\hline 14 & 4.63 & 4.5 & 90 \\
\hline 15 & 1.64 & 1.5 & 63 \\
\hline 16 & 1.80 & 1.5 & 62 \\
\hline 17 & 1.70 & 1.5 & 58 \\
\hline 18 & 2.35 & 3 & 63 \\
\hline 19 & 0.18 & 0 & 51 \\
\hline 20 & -0.39 & 0 & 50 \\
\hline 21 & -1.37 & 0 & 50 \\
\hline 22 & -2.30 & -3 & 48 \\
\hline 23 & -3.12 & -3 & 40 \\
\hline
\end{tabular}

According to the table data, diagram of dependences of voltage deviations in the main substation upon the power flowing through that line has been constructed (Fig. 5).

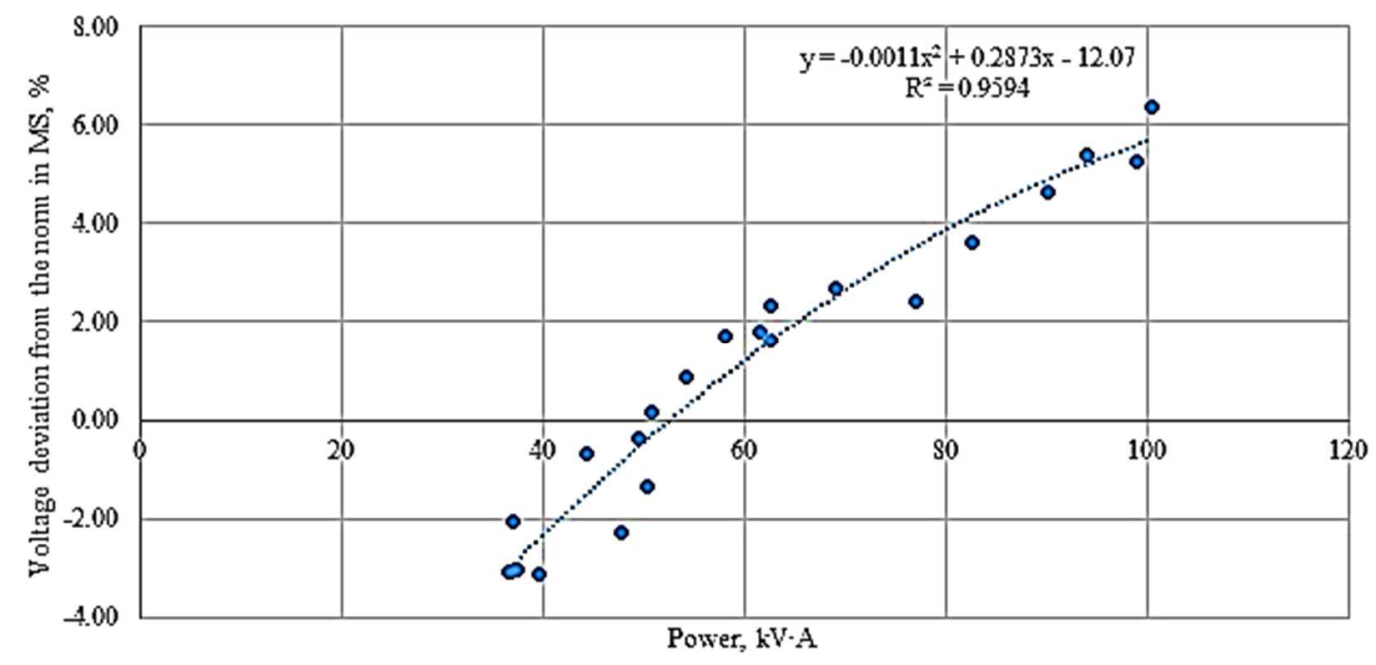

Fig. 5. Control mode for the network

With the help of approximation, maximally accurate dependence has been determined, i.e. polynomial one being represented in formula:

$$
V_{0}(S)=-0.0011 S^{2}+0.2873 S-12.07 \text {. }
$$

According to the data before and after the implementation of control, graphs of voltage deviations within the distribution transformer in terms of the farthest consumer has been constructed (Fig. 6, 7). Red lines display deviation norms being equal to $\pm 5 \%$.

Knowing the line parameters $(\mathrm{r}=0.64 \mathrm{Ohm} / \mathrm{km}, 1=0.95 \mathrm{~km})$, voltage losses before and after the implementation of energy-saving measures have been calculated and added to Table 4 .

Thus, apart from the improved voltage quality, one can observe decreased losses in the network as well. According to the electricity tariff, daily effect from the voltage control is $9.17 \mathrm{~kW} \cdot \mathrm{h}$ that is UAH 18.1 per day or UAH 6.501 thous. per year. 
TECHNICAL SCIENCES AND TECHNOLOGIES

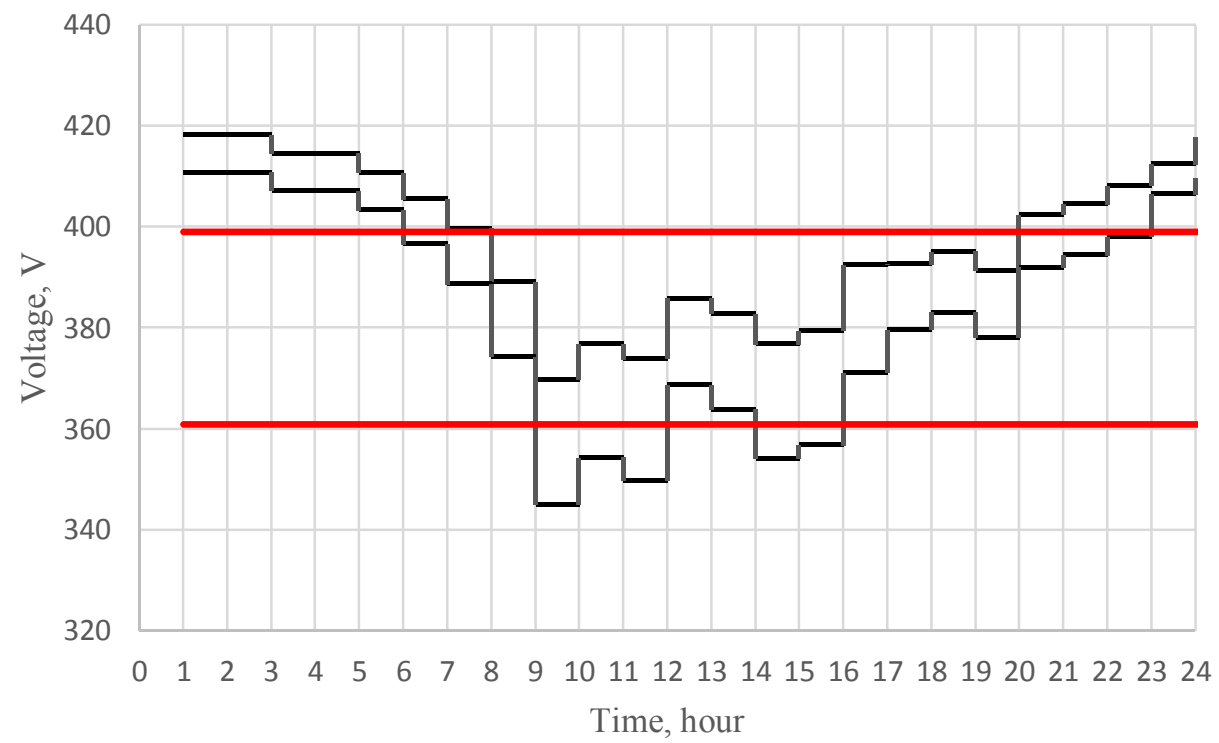

Fig. 6. Voltage deviations before the implementation of control

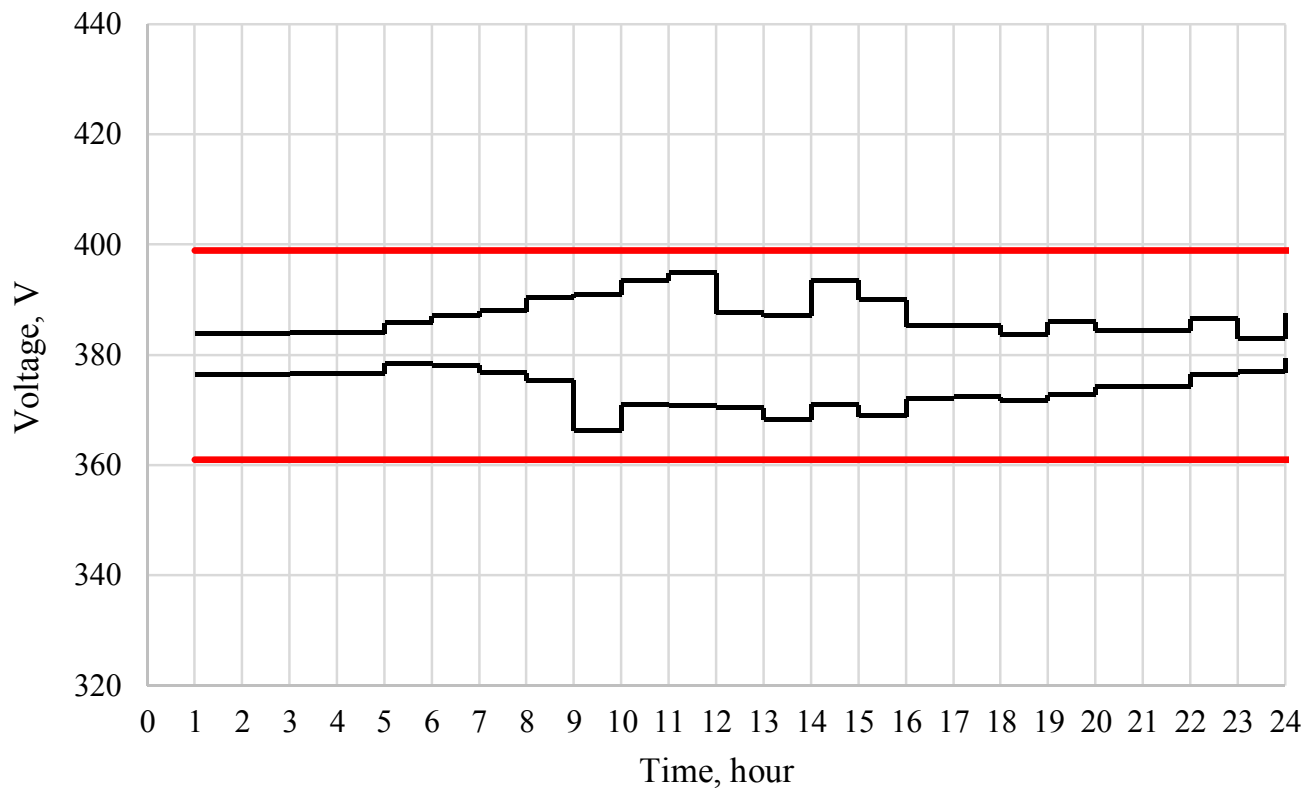

Fig. 7. Voltage deviations after the implementation of control

Effect from the implementation of control mode

Table 4

\begin{tabular}{|c|c|c|c|c|c|c|c|}
\hline \multirow{2}{*}{\begin{tabular}{c}
\multirow{2}{*}{ houre, } \\
hour
\end{tabular}} & \multicolumn{3}{|c|}{$\begin{array}{c}\text { Before the implementation } \\
\text { of control mode }\end{array}$} & \multicolumn{3}{c|}{ After the implementation of control mode } & \multirow{2}{*}{ Effect, $\mathbf{k W}$} \\
\cline { 2 - 7 } & $\begin{array}{c}\text { Voltage } \boldsymbol{U}, \\
\boldsymbol{V}\end{array}$ & $\begin{array}{c}\text { Current I, } \boldsymbol{A} \\
\boldsymbol{A}\end{array}$ & $\begin{array}{c}\text { Voltage losses } \\
\boldsymbol{P}, \boldsymbol{k W}\end{array}$ & \multirow{2}{*}{ Voltage $\boldsymbol{U}, \boldsymbol{B}$} & Current I, $\boldsymbol{A}$ & $\begin{array}{c}\text { Voltage loss- } \\
\boldsymbol{e s} \boldsymbol{P}, \boldsymbol{k W}\end{array}$ & \\
\hline 1 & 2 & 3 & 4 & 5 & 6 & 7 & 8 \\
\hline 0 & 411 & 91.2 & 5.06 & 376 & 99.5 & 6.02 & -0.96 \\
\hline 1 & 411 & 90.5 & 4.98 & 376 & 98.8 & 5.93 & -0.95 \\
\hline 2 & 407 & 90.7 & 5 & 377 & 98.0 & 5.84 & -0.84 \\
\hline 3 & 407 & 90.1 & 4.94 & 377 & 97.5 & 5.78 & -0.84 \\
\hline 4 & 403 & 91.7 & 5.11 & 378 & 97.7 & 5.81 & -0.7 \\
\hline 5 & 397 & 111.8 & 7.6 & 378 & 117.3 & 8.36 & -0.76 \\
\hline 6 & 389 & 139.7 & 11.86 & 377 & 144.0 & 12.61 & -0.75 \\
\hline
\end{tabular}


End Table 4

\begin{tabular}{|c|c|c|c|c|c|c|c|}
\hline 1 & 2 & 3 & 4 & 5 & 6 & 7 & 8 \\
\hline 7 & 374 & 184.5 & 20.7 & 375 & 184.0 & 20.58 & 0.12 \\
\hline 8 & 345 & 291.1 & 51.52 & 366 & 274.2 & 45.71 & 5.81 \\
\hline 90 & 354 & 265.1 & 42.73 & 371 & 253.1 & 38.94 & 3.78 \\
\hline 10 & 350 & 283.2 & 48.75 & 371 & 267.0 & 43.35 & 5.4 \\
\hline 11 & 369 & 208.9 & 26.53 & 370 & 207.8 & 26.27 & 0.27 \\
\hline 12 & 364 & 226.9 & 31.29 & 368 & 224.2 & 30.57 & 0.73 \\
\hline 13 & 354 & 265.4 & 42.84 & 371 & 253.4 & 39.04 & 3.8 \\
\hline 14 & 357 & 252.9 & 38.88 & 369 & 244.6 & 36.39 & 2.49 \\
\hline 15 & 371 & 168.6 & 17.29 & 372 & 168.2 & 17.21 & 0.08 \\
\hline 16 & 380 & 162.3 & 16.02 & 372 & 165.5 & 16.65 & -0.63 \\
\hline 17 & 383 & 151.8 & 14.01 & 372 & 156.4 & 14.88 & -0.87 \\
\hline 18 & 378 & 165.8 & 16.71 & 373 & 168.1 & 17.18 & -0.47 \\
\hline 19 & 392 & 129.8 & 10.25 & 374 & 136.0 & 11.25 & -1 \\
\hline 20 & 394 & 125.8 & 9.62 & 374 & 132.6 & 10.68 & -1.06 \\
\hline 21 & 398 & 126.6 & 9.75 & 376 & 133.9 & 10.9 & -1.15 \\
\hline 22 & 406 & 117.6 & 8.41 & 377 & 126.8 & 9.78 & -1.37 \\
\hline 23 & 410 & 96.7 & 5.69 & 380 & 104.4 & 6.63 & -0.94 \\
\hline & & & $\sum 455.54$ & & & $\sum 446.37$ & $\sum 9.17$ \\
\hline
\end{tabular}

Conclusions. Voltage deviation in the distribution networks has been performed and expediency of the voltage deviation control for electrically closest and farthest consumers have been analyzed in terms of Levanevska substation, town of Zaporizhzhia. Expediency of practical application of generalized diagrams for that purpose has been demonstrated.

It has been defined that in the modes of maximum and minimum loads, voltage exceeds the admissible deviation norms of $\pm 5 \%$. Conclusion has been made on the expediency of more careful voltage control. Generalized diagram for 0-1 and 9-10 hours with the maximum voltage deviations has been constructed. Graph of dependences has been developed; formula of voltage deviations in the main substation, due to the voltage passing along that line, has been defined.

According to the voltage data before and after the implementation of control, graphs of voltage deviations on the distribution transformer and in terms of the farthest consumer have been constructed.

\section{References}

1. GOST 13109-97. Normy kachestva elektricheskoi energii v sistemakh elektrosnabzheniia obshchego naznacheniia [Quality standards of electric energy in general-purpose electric power supply systems]. [in English].

2. Vorotnitskii, V. E. (2006). Poteri elektroenergii v elektricheskikh setiakh analiz i opyt snizheniia [Energy losses in electric networks: analysis and practice of its reduction]. Moscow: NTF Enrgoprogress [in Russian].

3. Zhelezko, Yu. S., Artemiev, A. V. \& Savchenko, O. V. (2002). Raschet analiz i normirovanie poter elektroenergii $v$ elektricheskikh setiakh [Calculation, analysis, and standardization of energy losses in electric networks]. Moscow: Izd-vo NTS ENAS [in Russian].

4. I 34-70-028-86. Instruktsiia po snizheniiu tekhnologicheskogo raskhoda elektricheskoi energii na peredachu po elektricheskim setiam energosistem i obieedinenii [Instruction to reduce technological consumption of electric power for the transmission through electric networks of electric systems and interconnections] (1987). Moscow: SPO Soiuztekhenergo [in Russian].

5. I 34-70-030-87. Instruktsiia po raschetu i analizu tekhnologicheskogo raskhoda elektricheskoi energii na peredachu po elektricheskim setiam energosistem i energoobieedinenii [Instruction to calculate and analyze technological consumption of electric power for the transmission through electric networks of electric systems and power interconnections] (1987). Moscow: SPO Soiuztekhenergo [in Russian].

6. Zgurovets, O. V. \& Kostenko, G. P. (2007). Effektivnye metody upravleniia potrebleniem elektricheskoi energii [Efficient methods to control electric energy consumption]. Problemy zahalnoi enerhetyky - Problems of general energetics, 16, 75-80 [in Russian]. 
TECHNICAL SCIENCES AND TECHNOLOGIES

7. Zhelezko, Yu. S., Artemiev, A. V. \& Savchenko, O. V. (2002). Raschet normativnykh kharakteristik tekhnicheskikh poter elektroenergii [Calculating normative characteristics of technical power losses]. Elektricheskie stantsii - Power stations, 2, 45-51 [in Russian].

8. Derzkii, V. G. \& Tokalin, O. A. (2001). Sistemnyi podkhod k vyboru meropriiatii posnizheniiu poter energii $\mathrm{v}$ raspredelitelnykh setiakh [System approach to select measures for power loss reduction in the distribution networks]. Energetika i elektrifikatsiia - Energetics and electrification, 10, 41-43 [in Russian].

9. Derzkii, V. G. (2002). Ekspertiza struktury poter elektroenergii vraspredelitelnykh setiakh Mintopenergo [Expert evaluation of the structure of power loss in the distribution networks of Mintopenergo]. Energetika i elektrifikatsiia - Energetics and electrification, 4, 18-22 [in Russian].

10. Derzkii, V. G. (2005). Rozrakhunok vtratelektroenerhii v rozpodilnykhmerezhakh $0,38 \mathrm{kV}$ [Calculating power losses in $0.38 \mathrm{kV}$ distribution networks]. Enerhetyka ta elektryfikatsiia - Energetics and electrification, 9, 32-40 [in Ukrainian].

11. Melnichuk, L. M. (2006). Vyznachennia ta rozpodilennia vtrat elektrychnoi enerhii mizh spozhyvachamy $\mathrm{z}$ urakhuvanniam yikh hrafikiv navantazhen [Determining and distributing power losses among the consumers taking into account the load diagrams]. Enerhetyka ta elektryfikatsiia Energetics and electrification, 5, 19-21 [in Ukrainian].

\section{УДК 621.396}

Віктор Коваленко, Сергій Левченко, Микола Трипутень, Віталій Кузнецов, Максим Трипутень, Олексій Городній, Аліса Кузнецова, Євгенія Кузнецова

\section{РОЗРАХУНОК РЕЖИМІВ РОБОТИ ХАРАКТЕРНИХ СХЕМ РОЗПОДІЛЬНИХ МЕРЕЖ З АНАЛІЗОМ ВІДХИЛЕННЯ НАПРУГИ Й ДОЦІЛЬНОСТІ ЇЇ РЕГУЛЮВАННЯ}

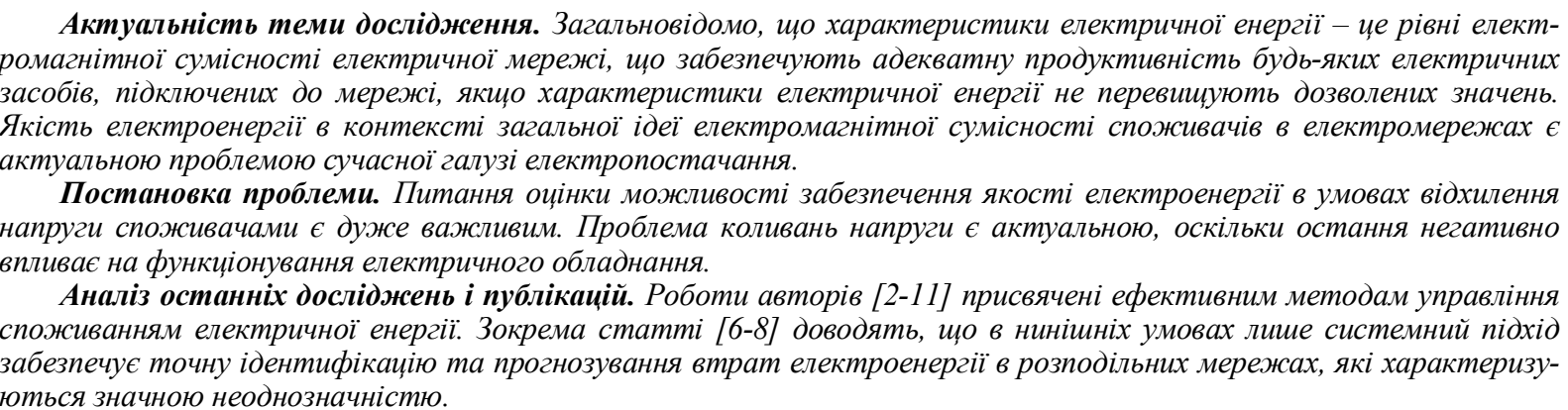

Виділення недосліджених частин загальної проблеми. Узагальнена діаграма (УД) режиму напруг характеризує стан одночасно для всієї розподільної мережі, приєднаної до иентру живлення (ЦЖ) і складається з розгалуженої мережі 10 кB, усіх розподільчих трансформаторів $і$ всіх мереж 0,4 кB, приєднаних до иих трансформаторів. Одночасно з узагальненою діаграмою отримано значення наявних величин втрат напруги, які при прийнятих умовах регулювання напруги в ЦЖ $і$ вихідних значеннях допустимих відхилень напруги у електроприймачів можуть мати місие в розподільних мережах 10 кB і 0,4 кВ. Крім того, звідси ж визначено робоче положення регулювальних відгалужень розподільного трансформатора.

Постановка завдання. Оскільки однією з важсливих характеристик електричної енергї̈ є відхилення напруги в мережі, дочільно провести ї̈ аналіз у міських розподільних мережсах на території підстанції Леваневська, м. Запоріжюся. Для спрощеного практичного уявлення про можливі режими напруги на шинах чентру жсивлення ЦЖ $і$ у всій розподільній мережі загалом дочільно використовувати графічну побудову - так звану узагальнену діаграму режсиму напруг. Аналіз режиму напруг за допомогою иієї діаграми є більш наочним, ніж аналітичний розрахунок, $і$ надає великі можливості.

Виклад основного матеріалу. Під час аналізу режиму напруги в розподільних мережах $і$ у прочесі визначення, зокрема, необхідного закону регулювання напруги в иентрі живлення ЦЖ доводиться враховувати велику кількість факторів, щъо впливають і великою мірою ускладнюють дослідження. До числа ции факторів відносяться: зміна режсиму роботи мережі, відмінність місиь приєднання електроприймачів ЕП до розподільної мережі, відмінність можливих робочих положень регулювальних відгалужень у розподільних трансформаторах РТ, відмінність місиь приєднання РТ до мережі 10 кB, наявність зони нечутливості у автоматичного регулятора напруги і $т$. ін. У зв'язку з иим доводиться проводити узагальнений аналіз режиму напруги й умов ї̈ регулювання в розподільних мережах $10 \kappa$ к і 0,4 кВ та на шинах ЦЖ спільно.

Для цієї мети слід застосовувати ймовірнісні методи розрахунків. У той же час для спрощеного практичного уявлення про можливі режими напруги на шинах ЦЖ $і$ у всій розподільній мережі в цілому доиільно використовувати графічну побудову - так звану узагальнену діаграму УД режиму напруг. Аналіз режиму напруг за допомогою иієі діаграми є більш наочним, ніж аналітичний розрахунок, $і$ надає великі можливості.

Висновки відповідно до статті. Проведено аналіз відхилення напруги в розподільних мережах $і$ дочільності його регулювання для електрично найближчого та найвіддаленішого спожсивача на прикладі підстаниії «Леваневська», м. Запоріжжя. Показано доцільність практичного застосування для иъього узагальнених діаграм. 
Виявлено, що в режсимах максимуму та мінімуму навантажень напруга перевищує допустимі норми відхилень $\pm 5 \%$. Зроблено висновок про дочільність більш ретельного регулювання напруги. Побудовано узагальнену діаграму для 0-1 та 9-10 годин, які мають найбільші відхилення напруги.

Побудовано графік залежності та знайдено формулу відхилення напруги в центрі живлення від потужності, щзо проходить по иій лінії.

За даними напруги до і після впровадження регулювання, побудовано графіки відхилення напруги на розподільчому трансформаторі й у найвіддаленішого споживача.

Ключові слова: розподільчі мережі; иентр живлення; відхилення напруги; навантаження трансформатора; регулювання напруги трансформатора РПН; узагальнена діаграма.

Табл.: 4. Рис.: 7. Бібл.: 11.

Kovalenko Viktor - PhD in Technical Sciences, Associate Professor of Department of Electrical Engineering and Energy Efficiency, Zaporizhzhya National University (66 Zhukovsky Str., 69600 Zaporizhzhya, Ukraine).

Коваленко Віктор Леонідович - кандидат технічних наук, доцент кафедри електротехніки та енергоефективності, Запорізький національний університет (вул. Жуковського, 66, м. Запоріжжя, 69600, Україна).

E-mail: kovalenko_v_1@i.ua

ORCID: http://orcid.org/0000-0001-5950-4412

Levchenko Serhii - PhD in Technical Sciences, Associate Professor of the Department of Electrical Engineering and Energy Efficiency, Zaporizhzhya State Engineering Academy (226 Sobornyi Av., 69006 Zaporizhzhya, Ukraine).

Левченко Сергій Андрійович - кандидат технічних наук, доцент кафедри «Електротехніка та енергоефективність», Запорізька державна інженерна академія (просп. Соборний, 226, м. Запоріжжя, 69006, Україна).

E-mail: levchenko s@rambler.ru.

ORCID: http://orcid.org/0000-0002-4355-5065

Tryputen Mykola - PhD in Technical Sciences, Associate Professor of the Department of Automation and Computer Systems, Dnipro University of Technology (19 Dmytriy Yavornytskyi Av., 49000 Dnipro, Ukraine).

Трипутень Микола Мусійович - кандидат технічних наук, доцент кафедри автоматизації та комп’ютерних систем, Національний ТУ «Дніпровська політехніка» (просп. Дмитра Яворницького, 19, м. Дніпро, 49000, Україна).

E-mail: nikolay.triputen@gmail.com

ORCID: http://orcid.org/0000-0003-4523-927X

Scopus ID: 57209004713

Kuznetsov Vitaliy - PhD in Technical Sciences, Associate Professor of the Department of the Electrical Engineering and Electromechanic, National Metallurgical Academy of Ukraine (4 Gagarin Av., 49000 Dnipro, Ukraine).

Кузнецов Віталій Вадимович - кандидат технічних наук, доцент кафедри електротехніки та електропривода, Національна металургійна академія України (просп. Гагаріна, 4, м. Дніпро, 49000, Україна).

E-mail: wit1975@i.ua

ORCID: http://orcid.org/0000-0002-8169-4598

Scopus ID: 57188644610

Tryputen Maksym - student, Oles Honchar Dnipro National University (35 D. Yavornitsky Av., 49000 Dnipro, Ukraine). Трипутень Максим Миколайович - студент кафедри обчислювальної математики та математичної кібернетики, Дніпровський національний університет імені Олеся Гончара (просп. Д. Яворницького, 35, м. Дніпро, 49000, Україна).

E-mail: triputen2014@i.ua

ORCID: https://orcid.org/0000-0001-6915-8162

Gorodny Oleksiy - PhD in Technical Sciences, senior lecturer of the Industrial Electronics Department, Chernihiv National University of Technology (95 Shevchenka Str., 14035 Chernihiv, Ukraine).

Городній Олексій Миколайович - кандидат технічних наук, старший викладач кафедри промислової електроніки, Чернігівський національний технологічний університет (вул. Шевченка, 95, м. Чернігів, 14035, Україна).

E-mail: aleksey.gorodny@gmail.com

ORCID: http://orcid.org/0000-0001-5303-9564

Web of Science: H-1425-2016

Scopus ID: 55327980200; 56338229500; 57191829796

Kuznetsova Alisa - student, Oles Honchar Dnipro National University (35 D. Yavornitsky Av., 49000 Dnipro, Ukraine).

Кузнецова Аліса Віталіївна - студентка, Дніпровський національний університет імені Олеся Гончара (просп. Д. Яворницького, 35, м. Дніпро, 49000, Україна).

E-mail: alisa20002014@i.ua

ORCID: http://orcid.org/0000-0003-4772-683X

Scopus ID: 57211399983

Kuznetsova Yevheniia - senior lecturer of the Department of humanitarian, fundamental and general engineering disciplines, National metallurgical academy of Ukraine (4 Gagarin Av., 49000 Dnipro, Ukraine).

Кузнецова Свгенія Валеріївна - старший викладач кафедри гуманітарних, фундаментальних та загальноінженерних дисциплін, Національна металургійна академія України (просп. Гагаріна, 4, м. Дніпро, 49000, Україна).

E-mail: wit_jane2000@i.ua

ORCID: http://orcid.org/0000-0003-2224-8747

Scopus ID: 57205606244

Kovalenko, V., Levchenko, S., Tryputen, M., Kuznetsov, V., Tryputen, M., Gorodny, O., Kuznetsova, A., Kuznetsova, Ye. (2019). Characteristic layouts of distribution networks with the analysis of voltage deviations and expediency of its control. Technical sciences and technologies, 3 (17), 209-218. 